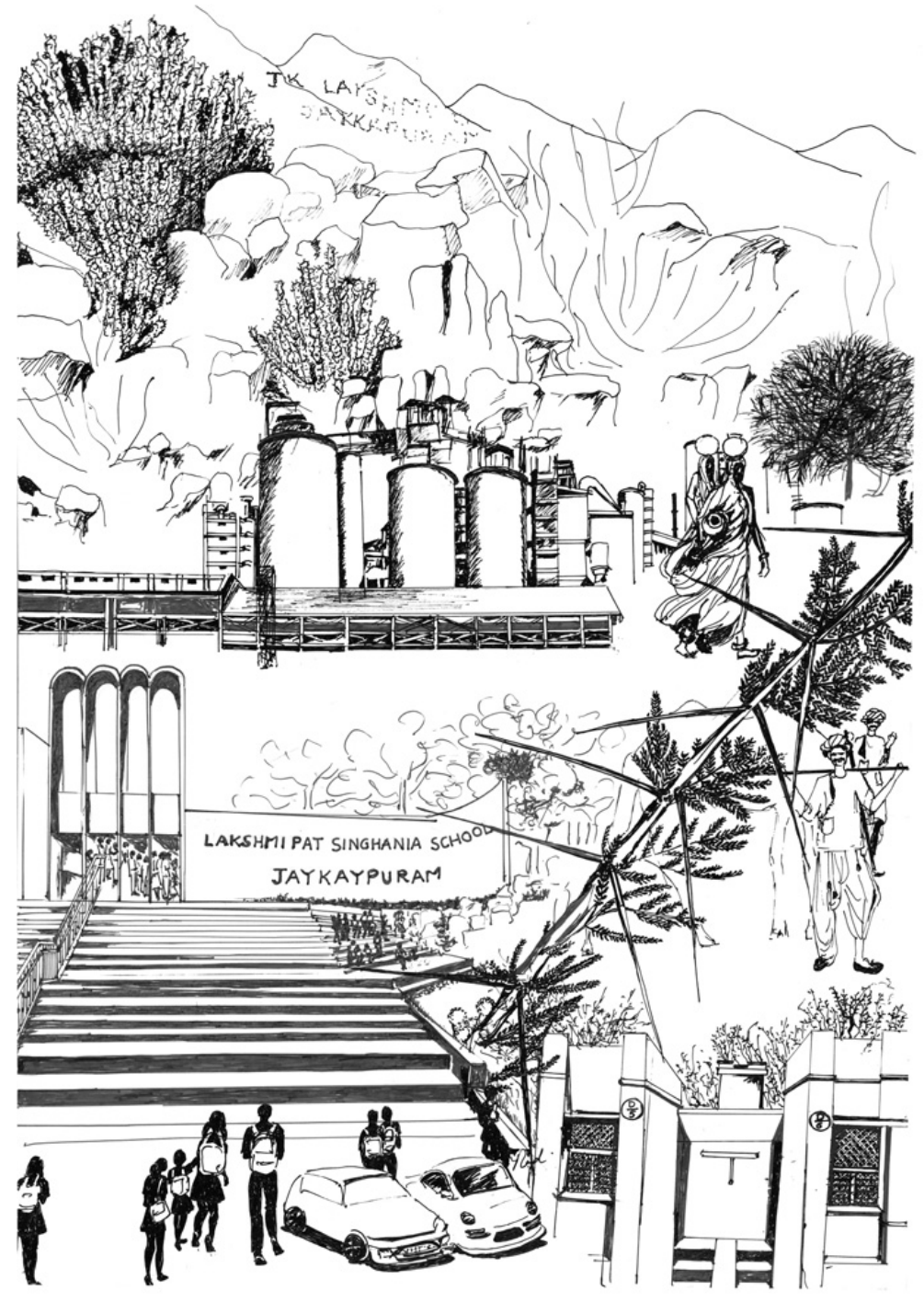

JK Puram is an industrial township in Rajasthan, flanked by the Aravalli hills and a cement factory. 


\section{SURVIVORS SHALL BE PROSECUTED}

One of my first memories of the place is cactus. Another is playing in piles of sieved sand that was waiting to be mixed into concrete.

The colony, a word often used to describe industrial townships and urban residential complexes in India, was dry and dusty. Summer temperatures inched towards fifty degrees centigrade. It was flanked on one side by the Aravalli hills, one of the oldest hill ranges in the world. On the other side stood a cement factory.

Everyone in this colony knew their place. Houses were allotted on the basis of jobs held at the factory. ' $A$ ' type quarters were for top management. These were spacious bungalows with a lawn and the services of a gardener. Upper management lived in ' $\mathrm{B}$ ' type, middle management in ' $C$ ' type, blue-collar workers in ' $E$ ' and ' $F$ ' type. We were in ' $D$ ' type, meant for those who were not quite managers but couldn't be classified as 'workers' either. People like my mother. She was vice-principal and later principal at a school meant for the children of factory employees.

The children of managers and furnace stokers attended the same school, but even 6-year-olds know how A-B-C-D goes. 'D' type was a cramped two-bedroom house with vertical iron bars on windows, doors of hewn planks, and concrete everywhere including the bathroom floor. No marble, no glass, no tiles, no garden. After my mother was promoted, one of my E-type friends had asked, 'I suppose you'll be hanging out with the C-type girls now?' 
I didn't know at the time that there was a ' $\mathrm{W}$ ' and an 'LC' too, quarters for watchmen and loaders respectively. I didn't see those quarters in the eleven years I spent there.

The roads were pure concrete - cement was one thing the township didn't lack - but traffic was almost non-existent. Only top management had cars; a few of the men rode scooters. Most of us just walked. Besides, there wasn't anywhere to go. No movie theatre, no restaurant, no shopping except for basic groceries, no café, no parks, no pools, no bookstore, no buses, no taxis.

If you needed to go out of the colony, you had to fill in a requisition form to ask for a car and driver. The district headquarters, Sirohi, was an hour's drive. It had a hospital where I was once admitted after a serious fracture and where I almost lost the use of a leg. It also had tailors' shops and bakeries. The cakes that mysteriously showed up on my birthday were made there. It had a railway station where, twice a year, we boarded a train to go visit my grandparents.

If you were desperate to escape without actually leaving the colony, your only recourse was the Aravalli hills. Ancient, stoic and never fully colonised, the hills were the reason the cement factory existed. Limestone deposits were torn out with explosives, and we were warned not to go climbing when a blast was scheduled. We never got to see the dynamite but we did hear the periodic boom! in the distance.

We'd climb the hill nearest the colony, sometimes with a sandwich picnic. Once there, we scratched our names on flat rocks with sharp-edged flint. Seeing my name, white on bluishgrey rock, brought cheap satisfaction: here I am, alive, but at risk of death by boredom.

We were warned not to climb the hills that couldn't be seen from the colony. There were stories about Bhil tribesmen who lived there and who could relieve kids of their valuables. We'd heard of petty theft in the colony - clothes taken off clotheslines, jars of clarified butter stolen from kitchens - and out on the highway, of robberies conducted after boulders were nudged off the slope onto approaching vehicles. 
I wasn't sure I believed the stories. Still, I didn't want to venture beyond the first row of hills. Scarier than being accosted and having my earrings taken away was the landscape itself: hill behind hill and beyond that, more hill. Not a soul in sight.

In the colony, everything revolved around the factory. Sirens summoned workers to their respective shifts, and we'd see them hurrying to work. Once in a while, a truck loaded with cement would rumble past.

Everyone I knew was an outsider who needed a job; everyone left as soon as a better opportunity presented itself. No outsiders were allowed in unless they were employees or their guests. The colony was gated and guarded. We never mixed with the children of farmers or shepherds who lived in villages barely a couple of kilometres away.

A township like this was a set of tasks and norms. It fed you but it didn't ground you. You couldn't, even if you wanted to, buy property here. Even if you were the sort of person who adored life in an industrial township, you couldn't stake a claim to it. On the other hand, those who did own land around here were near invisible. Nobody ever talked about what, or who, was here before the factory was built. I grew up with a sense that there was nothing before, and it wasn't hard to believe. There was enough cactus and acacia around to suggest a desert. Yet, there were fields of corn, sheep, cattle, a few camels.

We had glimpses of men in white dhotis and turbans, women in bright skirts. When a new building for the school was to be constructed, or a road had to be extended, they'd show up and I'd stare in wonder. Girls with distinctive tattoos and rows of metallic hairpins, men with earrings and tie-front shirts. Slowly, I learnt to tell the tribes apart - Garāsia, Rabādi, Bhīl.

The Rabādi were traditionally animal herders and they supplied us with milk. The Garāsia were farmers who came to work in the colony as wage labourers. Their children did not attend the school, though some teenagers came to work as domestic helps in the homes of colony residents. We didn't know how far they 
walked to get to the colony. None of us knew their languages. Their languages were not even recognised as such by the state. The factory, the school and living quarters of every 'type' had been constructed by the tribes who lived in surrounding villages.

Very few people have heard of JK Puram unless they had jobs here or family members were employees. Most people outside the state haven't even heard of Sirohi, the district in which the township is located.

Our nearest point of reference was Mount Abu, a 'hill station' that had once been used as a regional administrative centre by the British government and is now an affordable honeymoon destination in western India.

Mount Abu was where we would go for school picnics and field trips, and to write our final high school examinations. It was full of pretty picnic spots, but my favourite place was Trevor's Tank on account of its warning sign: swIMMING STRICTLY PROHIBITED. SURVIVORS SHALL BE PROSECUTED.

I used to think it was hilarious: to survive only to be prosecuted. I was too young to know what people did - or were willing to do to survive. I didn't fully understand private property or what legislating water or land meant. I did know that prosecution meant being hauled off by the police, and perhaps jailed. I didn't know what jail meant except what I saw in movies - it was a place where everyone wore uniforms and always wanted to escape.

I wanted to escape JK Puram and its sameness, its siren rhythms, the prickly things it concealed.

Twenty years passed before I returned to look at it with grown-up eyes. To speak with those who were here before and who would stay if the factory were to shut down. What was their relationship with outsiders who profited from the landscape that they traditionally saw as their own?

In Basantgarh village, I was introduced to Vaghta Ram. He listened intently while another activist explained my quest in the Garāsia language, then he thrust out his hands, which were 
covered in cement, and began to speak agitatedly. I had to interrupt: Hindi please.

He switched to Hindi. 'These hands built that place. All the old buildings, the factory, the-'

Slow down, I had to say. Begin at the beginning. In the beginning, he told me, about twenty Garāsia families lived on the land that became JK Puram. They farmed approximately 150 bighas collectively. There is no standard measure for a bigha in south Asia, but it could be anything between one third of an acre to one acre. ${ }^{1}$

Younger men had gathered around by now. Someone piped up, 'It was a thousand bighas!' Vaghta Ram shut him up firmly. I will not tell lies, he said, it was about 150 bighas.

It was not a place utterly devoid of state institutions or facilities. He is about 70 years old now and remembers that there was a government school in the village when he was a child. He was educated up to the eighth grade though classes were run under a tree, open to the sky, for the first five years. In the early 1970s, when he was in his mid twenties, land was acquired for a new factory and as part of the acquisition deal, the company promised to hire one man from each family as a permanent employee. The land was taken at nominal prices because in those days none of them knew what it was worth. They also didn't know that this place had been chosen because of its limestone deposits.

Vaghta Ram can account for thirteen men who got jobs, mostly in the packing or mining departments. He himself worked as a labour contractor and construction worker for twenty odd years, earning as little as 5 rupees as a daily wage at first. The kārigar (mason) earned the most: 9 rupees. Over the years, wages rose. But one thing remained constant - none of the Basantgarh workers were assigned living quarters inside the colony. Housing, they were told, was for those who needed it, which was outsiders. Workers from the surrounding villages walked between 2 and 5 kilometres each way. Kids whose fathers were not employed at the factory were not admitted to the colony school.

Resentment was slow to set in, but it had set in now. A young man, Praveen Singh Rao, cut into the conversation. His own 
father and uncle, he said, were due to retire in 2019. They were among the handful of men hired as 'permanent' employees. But Praveen could not attend the school my mother worked at a better school, after all, which offered an English medium education - because it was too far for a child to walk. Sacrifices were made eventually, for the sake of his younger siblings. The family rented rooms sublet by another employee, who had been allotted a colony house since he lived further away, but who owned a vehicle and didn't mind the commute.

The richer a man was, the more assets he possessed, the more money he stands to make, and the better educated his kids are, no matter his proximity to the workplace. Learning this lesson has angered Praveen. There are other resentments. Blasting for limestone in the hillside causes cracks in the walls of the homes of villagers. A dam has been built across the West Banas River, and it supplies plentiful water to the industrial township. It does not irrigate the fields of farmers. For their own drinking and basic household needs, the village has to buy water supplied by private individuals in tankers.

Vaghta Ram said he stopped working for the JK Group after one of his nephews fell to his death while working on a construction site. He filed a suit demanding compensation, but lost the case. He never wanted to work for the company again. That his hands are covered in cement now is on account of building something in his own village. He has a bit of land and he grows millets and corn.

I asked if farming wasn't harder work, with no guarantee of a good rain or a decent harvest? It is harder, he said, yet he feels more in control. On his own land, he isn't taking orders from another man. He is, however, of the old guard. Young men like Praveen are angry that a younger, better educated generation is not getting hired at the factory. Forty years have passed and Basantgarh sends no managers or engineers to JK Puram. Young people are not offered internships if they sign up for technical or engineering courses. Even girls are going to college now, including Vaghta Ram's daughters, but they aren't getting hired in the colony, which seeks only 'workers'. 
Even in the worker category, there is little hope of secure employment. Several departments have been outsourced by the manufacturer-industrialists to subcontractors. Jobs in construction, packing and loading are now going to labourers brought here from other states.

Is the 'outsider' labour much cheaper? I asked. No, I'm told. But outsiders are unlikely to organise, or expect anything bar wages. If they lose jobs, they are unlikely to make a fuss. They go home quietly.

Basantgarh is one of the villages 'adopted' by the industrial township. Relative to other Adivasi villages, more concrete is in evidence. There is no functional hospital with emergency facilities. The local health centre built by the government has an attendant nurse, but there is no resident doctor. This centre was locked when I visited, in the middle of a weekday afternoon. Occasionally the JK Group sends around a van with doctors, the villagers admit as much. However, these are not services people can rely on, or take for granted. The JK Puram school also admits children of non-employees now, but it is not free, nor so heavily subsidised as to benefit the poorest tribespeople.

The village is entitled to a limestone mining royalty and a small share of cement. The villagers agree, it is substantial money, but they allege that it gets cornered by the panchayat (village council) head. The last man who controlled the council also happened to be a union leader at the cement factory. He also happened to be a Rajput, not Garāsia. Nobody would say directly how the funds were used. Ask the factory people, some of the younger men said. Ask, how that man roams about in such an expensive car; how he can build a hotel where, it is rumoured, a cup of tea is going to cost 300 rupees? Ask, who pays for the fuel in his car?

I asked a different question: why did that man get elected when this village has a majority of Garāsia people? Nobody answered.

The story of losing power, then losing ground, is not a new one. In Rajasthan: A Concise History, Rima Hooja writes that a common 
motif in the founding narratives of many former kingdoms is Rajput warriors seizing power from forest- and hill-dwelling tribes. Folk tales and genealogies describe the overthrow of indigenous chiefs by Kshtriyas (ranked second highest in the Hindu caste hierarchy), who entered unfamiliar tracts either as refugees or invaders. To reassert sovereignty, and perhaps to affirm the loyalty of the tribes they conquered, kingdoms like Mewār and Dungarpur held coronation rituals where a Bhīl representative anointed the forehead of the Rajput successor.

Each kingdom had dozens of thikānās, fiefs controlled by Rajput feudal lords. Having lost their sovereignty, tribal communities now had to pay crushing revenues and dozens of additional taxes. They also had to perform forced labour, a practice called begār, and serve on hunting expeditions, for which they were not compensated. In some thikānās, they were also beaten for the smallest sign of intransigence, even if the intransigence had been enacted by the animals that were being hunted. $^{2}$

At various times, the tribes resisted. In 1839, Bhīl and Garāsia tribesmen killed some soldiers of the kingdom of Mewār, which led to the ruler setting up a military garrison to keep them in check. Sirohi, having signed a treaty with the British East India Company, also put down rebellions by Bhīls and Mīnas.

After a devastating famine at the turn of the last century, a tribal leader called Guru Govindgiri (originally Govinda Gobpalia) had emerged as a voice of resistance, but he was arrested and exiled, and very narrowly escaped the death penalty. Govindgiri had had a vision for the restoration of an indigenous kingdom - a Bhīl Raj - though he couldn't quite envision cultural autonomy. He spoke out against forced labour and taxes but also wanted his followers to give up meat and alcohol, which ran counter to Bhīl and Garāsiya culture. Other activists, too, were intent on the 'upliftment' of tribes and the 'modernisation' of their 'negative' lifestyle. ${ }^{3}$

Non-tribal, non-forest communities looked down upon tribespeople who lived by hunting, gathering forest produce, and practising a shifting form of cultivation. The administration also 
disapproved, partly because mobile groups couldn't be taxed very easily. After the early twentieth-century Land Revenue Settlement in princely states like Dungarpur, Sirohi and Banswara, the traditional rights of the tribes were further curtailed: shifting cultivation was forbidden, and access to honey, bamboo and other forest produce was cut off. ${ }^{4}$ Political resistance was crushed, often brutally.

Matters reached a head in 1920, with the 'Akki' or 'Eki' movement being suppressed by local rulers, British troops assisting. In May 1922, between 1,200 and 1,500 tribespeople were killed. Among the villages that were set ablaze was the village of Bhula in Sirohi.

When I texted him, asking to meet, he responded with his address and name drawn out to reflect a political consciousness of his identity: Mukesh Gameti Bhīl Adivasi.

He is, he says, the only man of his tribe from his village, Bhula, who has tackled competition. He uses 'competition' in the sense of taking exams that lead to government jobs. Going to college, travelling, paying fees - these are beyond the reach of most people in his community. He managed to graduate and land a job teaching at a government secondary school.

A lot has changed since the 1980s. For one, there are social networks and the Bhìl are starting to organise themselves. Mukesh is keenly aware of the movement for greater autonomy, spearheaded by the Bhil Autonomous Council, and the international recognition of indigenous rights. He is also aware of the political dependence of his people.

Bhīls, along with Mīnas, Garāsias, Sahariyas and several other indigenous tribes, are recognised as such by the Constitution of India and referred to as 'scheduled tribes', abbreviated to ST in common parlance. Electoral seats are reserved for them in state assemblies and in Parliament. Yet their interests, particularly the right to forest produce and water, are not safeguarded. Mukesh admits, representatives are often propped up by 'third parties', 
which is to say, larger political organisations. Whenever there is a conflict of interests, ST interests are betrayed.

I told him about growing up hearing stories about the Bhil on the other side of the hill, waiting to accost me and divest me of my earrings. He grinned. Bhula, he said, was once known to be a dangerous place. The people of his tribe who lived in the hills beyond JK Puram didn't lose farmland during the setting up of the township. What they did lose is impossible to articulate.

I asked Mukesh to try. He said, he'd heard that the land around the mining area was starting to turn barren. But there are no independent studies on environmental impact, no soil pollution data one could cite. Using the Right to Information, a law enacted in 2005, Mukesh wrote to the district magistrate, seeking information about the renewal of mining leases, royalties on limestone extraction, and whether 10 per cent of all permanent jobs were indeed reserved for local residents. He asked for a list of people who had those jobs. He got a reply telling him to seek the information from other departments.

Jobs were a flint that set off sparks of heat in every conversation. Strike enough times, and it comes back to the question of natural resources. Communities that were once dependent only on nature had to submit to others who took control of these resources, and this dependence is an uncertain one.

There are two labour unions now at the factory, where once there was only one. Both have relationships with major political parties. Neither has managed to secure more jobs for local residents. The JK Lakshmi Cement website has a sustainability tab. The 2014-16 report mentions initiatives aimed at maternal health awareness across thirty-five villages, and education programmes for differently abled children. ${ }^{5}$ But it does not mention how many jobs the factory can sustain. It does not offer data on the rate of employee hire by subcontractors or the gender profile of the workforce.

A scion of the family after whom the cement brand is named, Lakshmipat Singhania, is quoted in the report as saying: 'We seek a society which is proud of its past, conscious of the present and full of hope for the future.' 
The infographic below shows buildings in green hues, with solar panels, a human figure leaning to construct something, another figure putting litter in a bin, a bicycle. I was visiting the colony after twenty years, and saw few bicycles. There were more cars, although everything in the township is still within walking distance. I did see solar panels. The report mentioned that the company was getting into the business of renewable energy. It mentioned greenhouse gas and carbon emissions but said nothing about the environmental impact of blasting the ancient Aravalli hills for limestone.

There is another quote from one of the ancient spiritual texts, the Ishvasya Upanishad. It says: 'find your enjoyment in renunciation, do not covet what belongs to others'.

What belongs to whom? What, and how much, can be taken from nature? Who pays the costs of what is taken and cannot be returned? Tricky questions. To answer would mean to admit that belonging and coveting have to be seen through historical prisms, for it is history that informs narratives about what is ours to take, and what is not.

The rocks in the Aravalli hills near Sirohi are over 1,400 million years old. According to a 1981 census, the Adivasi or ST population in this district was over 23 per cent (it is now over 28 per cent). JK Lakshmi Cement was set up in 1982. According to the company's website, it boasts a turnover of 30 billion Indian rupees (418 million USD) and produces 13.30 million tonnes of cement a year.

The state, Rajasthan, leads on cement production, with limestone deposits in twenty-five of its thirty-three districts. Twentythree cement factories already exist. ${ }^{6}$ The limestone mining lease issued to JK Lakshmi Cement led to jobs for 204 people. ${ }^{7}$ We could assume that all of these jobs went to residents of the surrounding villages, though that would not necessarily be an accurate assumption.

What has been taken then, in lieu of what? 
Cactus remains entwined with my feeling for the place. One thorny memory is waking up to an undercurrent of violence beneath the sameness of life, with adults muttering about 'union' and 'strike'. On such days, we were sent home from school and told to be careful, not to loiter outdoors. Nobody explained, but the fence between 'worker' and 'management' was suddenly explicit.

Returning after two decades, I asked some of the older schoolteachers if they remembered such days. They did. One recalled having to escort the smaller children home, and added things were somewhat worse now. I asked why. She said, 'they' used bows and arrows to threaten the management before. Now there are guns.

The 'they' is undefined. It goes without saying that those who brandished bows and arrows were those who knew how to use them. What is not so clear is whether they brandished these arms in their own interest, for they have clearly not gained the upper hand.

Perhaps it is not so odd, after all, that an industrial township should be called a 'colony'. It is not a town that has sprung up organically, in response to the needs of those who live there. Factories usually make profits for outsiders who live elsewhere, speak other languages, are likely to bury or scatter the ashes of their beloveds elsewhere. This, at least, they have in common with systems that render entire nations 'colonies'.

Those who worked in JK Puram as managers over the last few decades didn't need to learn the language of the Adivasis. They would not have known the tribes' ballads, or the logic of their marital customs. They came as outsiders, and left culturally unchallenged. It was the Adivasis who had to adapt, learning Hindi and English. I could talk to them without an interpreter. They did not refuse to talk to me, but there was little doubt in either of our minds that I came speaking the language of power, and that the balance of power was tilted against them.

I wonder what it might have been like if the dreams of early twentieth-century activists had been realised: what if the factory was located in a Bhīl Raj, or a Garāsiya Raj? 
Would we study Bheeli as a first or second language in schools? Would we have committed to a different strand of collective memory: singing paeans to Adivasi heroes, absorbing their aesthetic, learning skills like hunting, sculpting and farming?

There are fresh attempts at reclaiming indigenous territories. A political outfit called the Bharatiya Tribal Party won two seats in the 2018 state assembly elections. It is demanding a separate state made up of lands that have a significant Bhill population. One of its leaders pointed out in an interview that a distinct political 'state' is crucial for the preservation of cultural identity, which some activists are trying to erode. ${ }^{8}$ Despite being Bhîl themselves, they want their people to 'imitate the general population'.

Bhīl and Garāsiya culture is different from the 'general' or, more specifically, upper-caste norm. This reflects not only in body language but in emotional and sexual practices.

As a teenager, I used to watch the girls who came to work in the colony with a mix of fascination and nervousness. Their skirts took in several yards of fabric and their odhnis (a type of sari) were used more as practical scarves/sun shields than as an aide to modesty. They wore tattoos, sometimes their own names stamped on their forearms. On hot summer afternoons, they would push long blouses up so the breeze could touch their bellies and backs. The girls laughed easily, and even as a child, I saw that the way they walked, talked, looked at others was less inhibited than peers in the 'general' population.

Occasionally, an Adivasi girl who worked in someone's home would disappear. We heard whispers about the girl having eloped. To non-tribal girls, this was an incredible act, a source of undying shame. But a few months later, the girl would reappear, clearly unashamed. Sometimes we'd hear that a girl had left the man she'd eloped with. The gossip was accompanied by tut-tutting on the part of colony aunties and comments like, 'These things happen among these people.'

I caught a note of distress along with contempt, but was too young to know of cultural wars. 'These people' were indigenous 
or 'mool nivasi', as they are officially acknowledged to be, the earliest inhabitants of the land. Tut-tutting aunties were groomed to see upper-caste marital practices as the norm, where marriage was arranged and divorce forbidden, and any deviation was punished through social ostracism. To see the norm challenged so easily, to see that it caused no significant damage to the girls, was distressing to them.

Among many tribes in India, there is a tradition of bride price rather than dowry. Therefore, there is a tradition of elopements among young couples if the boy cannot negotiate a price that meets expectations. There is also a tradition of living together without performing wedding rituals, which continues to raise brows. The Hindi press tends to write headlines such as 'Livein ... a Jaw-dropping news about the tribes' (sic). ${ }^{9}$

The Adivasi leadership wants no mainstreaming. What it wants is water access, rights over natural wealth such as minerals and marble, and preventing 'outsiders' from buying Adivasi lands. ${ }^{10}$

This is a common demand by tribes in hill and forested areas. Laws have been framed in some states that limit the right of Indian citizens' to acquire land unless they can prove local residency for a certain number of years. This is partly to protect the rights of the poor, who may not know the market value of their lands, partly to ensure that the demographic does not change suddenly. Perhaps there is an additional concern about land being controlled by those who are not deeply invested in the local ecology and economy.

The rules are frequently relaxed for politicians, religious organisations and industrial houses, of course. In fact, the government steps in to acquire land on behalf of industrialists and protests are overcome with the help of police or the armed forces. Often this ends with the killing or the jailing of activists and local leaders.

Emblazoned in giant white letters across the bosom of a hill that overlooks the colony is its name: JAY KAY PURAM. It can be seen from the windows of trains that chug through the area. 
Seeing the name was exciting to the child who lived there. Looking at it with adult eyes, it seemed to have been planted like a flag of dominion. The initials ' $\mathrm{J}$ ' and ' $\mathrm{K}$ ' stand for Juggilal and Kamlapat Singhania, the founders of a business house that works in several sectors, including cement and tyre manufacture. For the sake of cement manufacture, the hills had to be blasted, limestone extracted. Rivers would supply water. Ground water would be extracted too. Perhaps it was necessary that the place be named for those who controlled not just the land but its resources.

Living under the shadow of that name, I had not interrogated such controls over nature and mineral. I started doing so only after I met communities that had been stripped of all the things that sheltered and nourished them - food, herbs, wood, water, cultural autonomy. On one assignment, I was on a bus with a group of activists on a journey to campaign for a law that granted citizens the right to work. The bus went through Rajasthan, north to south.

I was on familiar ground, and yet nothing seemed familiar. Adivasis, their concerns and goals, were different from those of the industrial township residents. At one public meeting, women began to speak about what it meant to not own land. It was not just the lack of a field to till, or a square upon which to build a house; it was also about not having anywhere to squat and shit without the fear of being attacked. It is impossible to live without fear on a daily basis, without land and water rights.

In 1927, the British passed a law bringing forests under the direct control of the government. This law has remained in force in India, and those who live in forests are considered encroachers unless they can prove otherwise. Since independence, around 50 million Indians have been displaced to make way for dams, industrial projects, highways and protected forest reserves. ${ }^{11}$ The majority of the displaced, over 40 per cent, were Adivasis, who comprise only 8 per cent of the population. ${ }^{12}$ If they refused to go quietly, they were evicted through brute measures including the use of elephants to knock down huts; their crops were destroyed and their homes set on fire by the state's paramilitary forces. ${ }^{13}$ 
Adivasis have tried to insist upon their right to stay within forests or to resist mining operations. There have been arrests and gunfire. One of the rare times a community did win a battle against an industrial giant, it was by insisting that the mountain was sacred; it could not be destroyed because it interfered with religion. Speaking of their right to live where their forefathers have always lived was not an acceptable argument. That just got them charged with rioting and other crimes. ${ }^{14}$

The Supreme Court of India has reaffirmed the state's right to evict over a million Adivasis living in forests, although studies indicate that forest dwelling communities find it hard to survive if separated from their traditional ways of life. To be removed from the forest is to be sentenced to a lack of bread and meat, fruit and flower, wine and wood.

Studies also indicate that rehabilitation rarely works - to be given a piece of land in a new location in return for access to a forest and community networks is a bargain so skewed, it is hard to enumerate. What can be enumerated is poverty and wealth. A study jointly undertaken by the Savitribai Phule Pune University, Jawaharlal Nehru University and the Indian Institute of Dalit Studies has found that a little over 22 per cent of India's upper-caste Hindus own 41 per cent of the country's wealth while the 7.8 per cent that comprise the scheduled tribes own just 3.7 per cent. The wealthiest 1 per cent own 25 per cent of the country's total assets, including land, while the bottom 40 per cent of households own just 3.4 per cent. ${ }^{15}$

Adivasis, displaced often, end up in cities where they are reduced to penury and homelessness. A recent study of fifteen cities across five Indian states has found that scheduled castes make up the largest proportion of the urban homeless, at 36 per cent, followed by scheduled tribes, who comprise 23 per cent. Worse, it isn't a temporary phase. Sixty per cent of the surveyed homeless had been born in the same city, which means their parents were possibly homeless too. ${ }^{16}$

Yet another study indicates that 50 per cent of India's Adivasi population is poor based on every indicator, 
including nutrition, health, education, living standards and ownership of assets. ${ }^{17}$ So poor that some families in Rajasthan have ended up mortgaging children. ${ }^{18}$ And what are the chances a mortgaged child can find a way to come back home? 